\title{
A revision of Hoya (Asclepiadaceae) in Australia
}

\author{
K.D. Hill
}

\begin{abstract}
Hill, K.D. (National Herbarium of New South Wales, Royal Botanic Gardens, Sydney, Australia 2000) 1988. A revision of Hoya (Asclepiadaceae) in Australia. Telopea 3(2): 241-255. - Australian representatives of the genus Hoya R. Br. (Asclepiadaceae) are reviewed. Three new species are described, one with two subspecies (H. alata, H. rupicola, H. oligotricha, H. oligotricha ssp. tenuipes); $H$. sana is reduced to subspecific status within $H$. australis; and $H$. keysii and $H$. dalrympleana are included in $H$. australis ssp. australis. A review of infrageneric division of Hoya is presented with reference to Australian species. Description of a further Australian species in a new genus is foreshadowed.
\end{abstract}

\section{Introduction}

Hoya is a predominantly South-East Asian genus of about 200 species, distributed from India, southern China and Japan through Indochina and Malesia to northern and eastern Australia and the south-west Pacific Islands. The taxonomy of the group is confused, with over 500 published names, many with inadequate (although valid) descriptions and incomplete types. Recent studies by Backer \& Bakhuizen (1965) and Rintz (1978) have contributed some order to the Javanese and Malaysian representatives of the genus, but such regional works do not address the problem of the numerous different names existing in neighbouring areas for possibly identical species. Problems at generic and infrageneric levels also have not been resolved by regional studies.

Nomenclature in Papua New Guinea and the South Pacific remains chaotic, with a plethora of names, many of which have not been applied beyond the type specimen.

One group of taxa, represented in Australia by a single undescribed species, differs markedly in a range of key diagnostic characters from Hoya sens. strict. A study of Hoya and related genera has led to the removal of this group to a new genus (Eriostemma (Schltr.) K. Hill, Hill in prep.). The remaining species of Hoya in Australia are part of a clearly defined and natural group.

Hoya apparently reaches maximum diversity in New Guinea. The Australian species have arisen from sporadic dispersals from New Guinea, and represent several divergent lineages within the genus. Consequently, they are not particularly closely related to each other. The group has not diversified or dispersed extensively in Australia, and a number of species are restricted to Cape York. The limited botanical exploration of this area has meant that several of the Australian taxa have remained undiscovered until recently, and hence are undescribed.

The present study concerns the Australian representatives only. The Malesian and Pacific collections of LAE and CANB have been examined, and it has been established that the species herein described as new are not represented in those collections. Future studies may, however, establish that 
these taxa occur outside Australia and do have earlier names. In the absence of resources to monograph the entire genus, a delimitation of the Australian species only is considered desirable and expedient. This will draw attention to these taxa, ensuring treatment in any future monographic study and consideration in relevant ecological, land use and conservation studies. The latter considerations in themselves justify the production of an interim study as part of an overall cataloguing of the biological resources of Australia.

This study is based on examination of living and preserved materials. All taxa have been studied as populations in the field. Herbarium collections from NSW, BRI, MEL, PERTH, CANB, CBG and LAE have been examined, including dried and spirit-preserved material. All types have been seen, unless otherwise indicated. A comprehensive living collection of all Australian taxa is maintained by the Royal Botanic Gardens, Sydney, and this collection has been studied in detail. Specimens marked ' + ' in the specimen citations are vouchers taken from cultivated specimens in this collection.

\section{Taxonomic history}

Hoya was described by Robert Brown (1810), although plants of the genus were known from well before that time (e.g. Rumphius 1749). Brown described two species, one of which has since been placed in another genus (Hoya viridiflora $\mathrm{R}$. Br., = Dregea volubilis (L.f.) Benth. ex Hook. f.). The other was based on Asclepias carnosa L.f., with the cited locality in the original protologue of 'Habitat in China'. In his enlarged circumscription of Hoya carnosa, Brown included several taxa distributed from China to Australia, and noted that he thought a number of species might be involved. The first Australian species recognized was $H$. australis, which was separated from $H$. carnosa by Traill (1830), based on material collected by Banks and Solander in 1770 at the sites of Cooktown and Cairns (Britten 1898). This taxon had been distinguished by Brown, who had annotated herbarium sheets with the name but not published it. The same taxon was subsequently described (as $H$. dalrympleana $\mathbf{F}$. Muell. and $H$. keysii Bailey) by other authors who thought that the name $H$. australis represented the common species in New South Wales and southern Queensland. The next Australian species was recognized by Mueller, who described $H$. nicholsoniae in 1866. Bentham (1869) recognized three taxa in 'Flora Australiensis'. These were $H$. nicholsoniae, $H$. australis (in which he included all species of the $H$. australis complex known at that time) and $H$. carnosa (erroneously - see discussion under that name). Subsequent treatments of the genus in Australia were largely abstracted from Bentham with some additions (e.g. Bailey described $H$. keysii in 1884 and $H$. sana in 1897). The most recent addition was H. macgillivrayi, described by Bailey in 1913.

\section{Comparative morphology}

\section{Habit}

Plants are usually climbers with long internodes and glabrous or hairy stems. Some extra-Australian species are secondarily shrubby, with short internodes. Climbing is by means of twining stems, 'anchor' leaves (see below) and short, branched adventitious roots. Many species germinate terrestrially and climb into trees, eventually losing contact with the original root system and becoming wholly epiphytic. 
Plants of the $H$. australis complex display a dimorphic growth habit. Young plants have short internodes and are basally branched, to produce a multistemmed shrubby plant. Plants may remain as such in extremely harsh conditions, and reach full maturity as shrubs. In favourable conditions, the short shoots produce extended shoots apically, with long internodes and a twining habit. These vine growths take root by means of adventitious roots where they come in contact with suitable substrates, generating shrubby plants which repeat the cycle. Plants may thus vegetatively propagate to cover wide areas.

\section{Leaves}

Leaves are opposite and decussate, glabrous or hairy, and highly variable in size, shape and venation. Hairs are simple or uniseriate, thin-walled and sharppointed, and vary in size and degree of appression. Texture varies from moderately to extremely succulent, depending somewhat on the habitat. A group of possibly nectariferous glands is characteristically present at the junction of the petiole and the lamina.

Mesophyll varies from undifferentiated through weakly differentiated to strongly differentiated, with a gradual transition from palisade to spongy tissue in the differentiated types. Sclerenchymatous mesophyll fibres are usually present, and vary in abundance, length and wall thickness.

Leaves of some groups are distinctively spotted silver, grey or pale green due to irregularly concentrated chromoplasts in cells immediately underlying the adaxial epidermal cells. Primary venation may be brochidodromous (broadly pinnate with a looped intramarginal vein), or acrodromous (with three, five or seven principal veins arising near the junction of lamina and petiole). In many cases, petioles are held at right angles to the stem, and the leaf lamina is reflexed a further 90 degrees to the petiole. This structure creates an 'anchor' effect, by which the developing leaf pairs are entrapped in surrounding vegetation, and hence contributes to the climbing habit.

\section{Inflorescences}

Inflorescences are 'interpetiolar' (representing terminal shoots in a modified sympodial growth habit - see Demeter 1922), and are consequently produced only at the tips of actively growing branches. They are indeterminate and perennial, modified pseudo-monochasial cymes. Numerous successive flushes of flowers are produced over a number of years, during which time the rhachis continues to elongate (a few extra-Australian species have secondarily shortlived umbelliform inflorescences). Each flush of flowers appears as an umbel, due to extreme reduction of the penultimate floral internode. Individual flowers become apparently spirally inserted on the rhachis or on a short side-shoot on the rhachis as a consequence of this reduction.

Three types of inflorescence may be recognized:

1. Umbel globular with equal pedicels; ageotropic.

2. Umbel flat or concave, with pedicels longer to the outside; positively geotropic.

3. Umbel flat, with pedicels longer to the outside and rigidly erect; negatively geotropic.

Types 1 and 2 occur amongst the Australian species. 


\section{Flowers}

Flowers are 5-merous and radially symmetrical, with valvate aestivation. Sepals are free, often with minute basal glands inserted either on the sepal margins or on the floral axis between the calyx and the corolla. The corolla is basally connate, glabrous or hairy, and may be campanulate or reflexed with the lobes further recurved. The corona is staminal in origin, usually large and prominent, and highly variable in shape and orientation. Each scale, which is derived from the staminal filament, has two proximal lobes or keels. These are inrolled to create a cavity (Fig. 1). Anthers are basally cleft, with lobes lying on either side of the filamental scale, and apically produced into a membranous wing which lies over the stigma. Pollen sac contents are fused into pollinia, and adjacent sacs of contiguous anthers are joined by caudicles to a corpuscle (Fig. 1). The caudicles and corpuscle are non-cellular, and generated by stigmatic secretion. Pollinia are erect and winged, the wings being composed of sterile pollen grains. Caudicles may or may not be winged.

\section{Infrageneric classification}

Within the Asclepiadaceae, Hoya is placed in the Tribe Tylophoreae, subfamily Asclepiadoideae. A subtribe Marsdeniineae has been recognized in the past, but this is defined by primitive characters (symplesiomorphies) of no grouping value. At this level, several groupings may be delineated on advanced characters (synapomorphies). One group is the Hoya 'alliance', characterized by valvate floral aestivation, a large staminal corona, shortly stalked pollinia and a flat, deeply lobed corolla. Within this group Hoya is defined by perennial but sometimes secondarily short-lived inflorescences; winged pollinia; linear fruit with limited pericarp; and deep, inrolled coronal keels.

A number of systems of infrageneric classification have been proposed in the past, but these have been largely incomplete. As with many such systems, several groups with distinctive advanced or primitive characters are established, and a large, amorphous remainder (paraphyletic residue) relegated to a category of convenience. Schlechter (1913) recognized seven Sections (based in part on Schumann, 1885) for the 50 species he recorded in German New Guinea, 25 of which fell into the residual Section 'Euhoya'.

A full revision of infrageneric classification is beyond the scope of this study, so Sections recognized by Schlechter (op. cit.) will be accepted with some modification. Sections present in Australia are as follows:

1) Hoya (in part Euhoya Miq., Fl. Ned. Ind. 2: 516 (1857), as treated by Schlechter).

Peduncles ageotropic. Pedicels equal. Corolla reflexed. Coronal scales narrowly to broadly trapezoidal, flat above with a slight median ridge, inner and outer angles acute. Caudicles unwinged. Mesophyll weakly differentiated or undifferentiated. Epidermal spotting often present (diffuse or sometimes absent in some Australian plants).

A large and widespread group, extending from China to the South Pacific. One species in Australia (H. nicholsoniae).

2) Physostelma (Wight) Schltr., Bot. Jahrb. Syst. 50: 105 (1913).

Peduncles ageotropic. Pedicels equal. Corolla campanulate. Coronal scales 


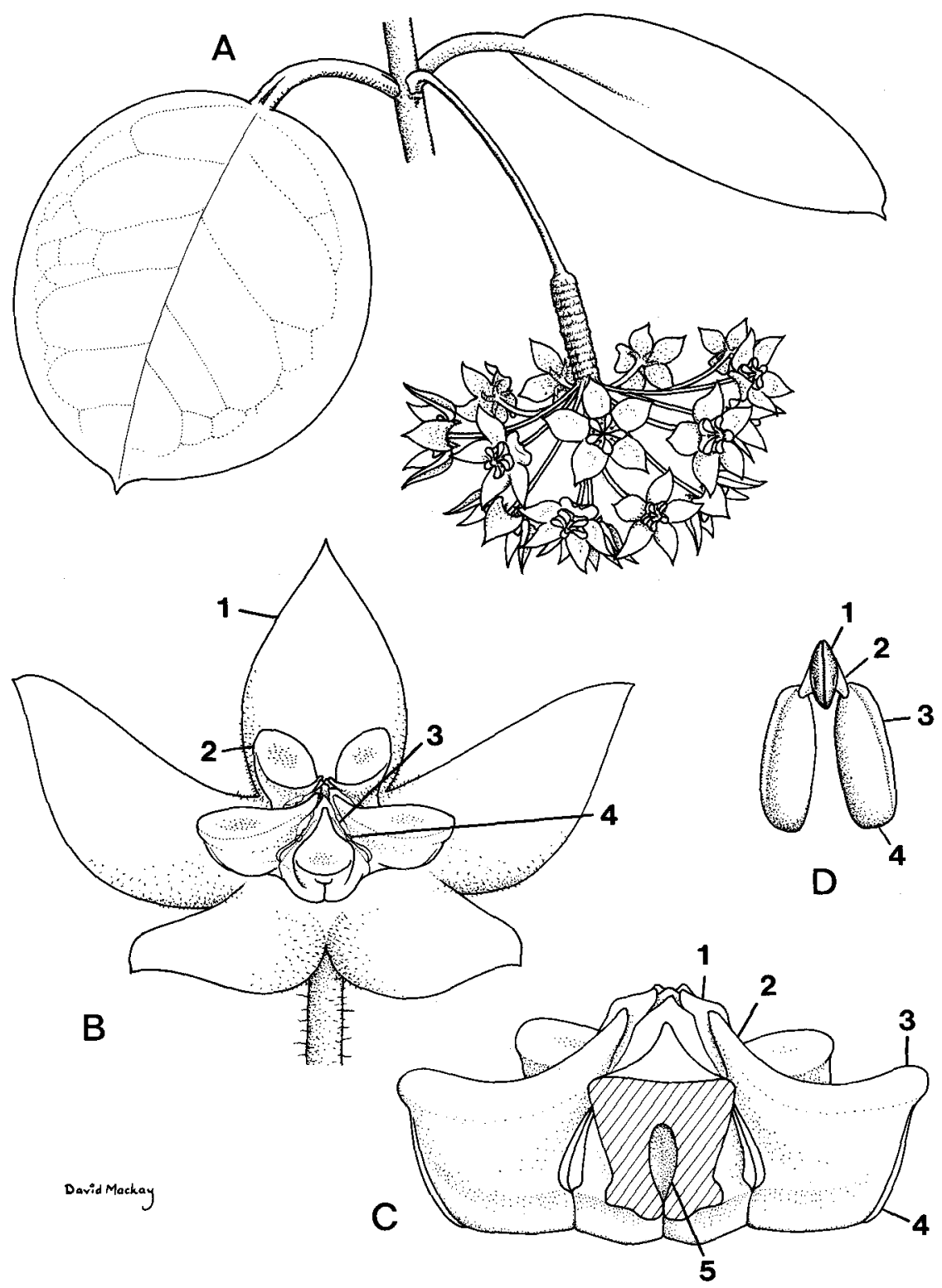

Fig. 1. Hoya australis R. Br. ex Traill subsp. australis. A, habit (X .8): showing interpetiolar inflorescence, elongated rhachis with scars from previous flowerings, and rounded umbel with equal pedicels. B, flower (X 4): 1. Corolla lobe. 2. Corona scale. 3. Position of pollinia. 4. Corpuscle. C, corona (X 11): 1. Membranous apical anther wing. 2. Inner angle of corona scale. 3. Outer angle of corona scale. 4. Keel of corona scale. 5. Transverse section of scale, showing cavity enclosed by keels. D, pollinarium (X 23): 1 . Corpuscle. 2. Caudicle. 3. Sterile wing. 4. Fertile body of pollinium. (From P. Hind 244.) 
oblong-linear, rounded above, inner angle acute, produced forward, outer angle rounded, produced forward. Caudicles unwinged. Mesophyll strongly differentiated. Epidermal spotting absent.

A small group, distributed from Malaysia and the Philippines to the South Pacific. One species in Australia (H. macgillivrayi).

3) Otostemma (Bl.) Miq., Fl. Ned. Ind. 2: 525 (1857) (here including part of 'Euhoya' of Schlechter).

Peduncles geotropic. Pedicels unequal. Corolla reflexed. Coronal scales narrowly trapezoidal, flat above with a slight median ridge, inner and outer angles acute, inner angle somewhat raised. Caudicles winged. Mesophyll weakly differentiated. Mesophyll fibres abundant, long, thick-walled. Epidermal spotting present.

A small group with a similar range to the above. One species in Australia (H. alata).

4) Pterostelma (Wight) K. Schum., Nat. Pflanzenf. 4(2): 289 (1895) (in part as treated by Schlechter, and including the $H$. australis complex, which that author included in 'Euhoya').

Peduncles ageotropic. Pedicels equal. Corolla campanulate. Coronal scales ovate, concave above, inner angle apiculate, outer angle rounded. Caudicles unwinged. Mesophyll differentiated. Epidermal spotting absent.

A small group, centred on Australia and the South Pacific, with one species extending to Indochina. Four species and 3 subspecies in Australia (the H. australis complex).

\section{Key to the sections}

1 Caudicles winged, pedicels unequal Section Otostemma

$1^{*}$ Caudicles not winged, pedicels equal

2 Corolla reflexed Section Hoya

2* Corolla campanulate

3 Corona scales oblong-linear, convex above, inner angle produced forward Section Physostelma

$3^{*}$ Corona scales ovate, concave above, flat, inner and outer angles more or less level Section Pterostelma

\section{Taxonomy}

Hoya $R$. Br., Mem. Wern. Nat. Hist. Soc. 1: 27 (1810)

TYPE: $H$. carnosa $\mathrm{R}$. Br.

Sperlingia Vahl, Act. Hafn. 6: 113 (1810)

TYPE: $S$. verticillata Vahl (Hoya verticillata (VahI) G. Don)

Schollia Jacq. f., Ecl. PI. Rar. 1: 5, t. 2 (1811)

TYPE: $S$. crassifolia Jacq. f. (Hoya carnosa $\mathrm{R}$. Br.)

Pterostelma Wight, Contrib.: 39 (1834)

TYPE: P. acuminata Wight (Hoya acuminata (Wight) Benth.)

Physostelma Wight, op. cit.: 40

TYPE: P. wallichii Wight (Hoya campanulata $\mathrm{Bl}$.) 
Cyrtoceras Benn., Pl. Jav. Rar.: 90, t. 21 (1838)

TYPE: C. reflexum Benn. (Hoya multiflora $\mathrm{Bl}$.)

Centrostemma Decne., Ann. Sci. Nat. (Paris) ser. 2(9): 271, t. 12 (1838)

TYPE: multiflorum (BI.) Decne. (Hoya multiflora B1.)

Cystidianthus Hassk. in Hoev. \& de Vriese, Tijdschr. Natuurl. Gesch. Physiol. 10: 125

(1843)

TyPE: C. campanulatus (B1.) Hassk. (Hoya campanulata Bl.)

Acanthostemma B1., Mus. Bot. 1: 57, t. 10 (1850)

TYPE: A. rumphii (Bl.) Bl. (Hoya rumphii $\mathrm{Bl}$.)

Cathetostemma Bl., op. cit.: 59, t. 13

TYPE: C. laurifolium (Decne.) Bl. (Hoya laurifolia Decne.)

Otostemma Bl., op. cit.: t. 11

TYPE: O. lacunosum (B1.) Bl. (Hoya lacunosa Bl.)

Plocostemma Bl., Rumphia 4: 30 (1849)

TYPE: P. lasiantha Korth. ex Bl. (Hoya lasiantha (Korth. ex Bl.) Miq.)

[Triacma van Hass. ex Miq., Fl. Ned. Ind. 2: 523 (1857), in syn., nom. nud. (= Sperlingia Vahl)]

Glabrous or tomentose shrubs or twiners, terrestrial or epiphytic, with short or long internodes. White or clear latex present in all parts except flowers. Leaves succulent, opposite, decussate, with broadly pinnate or palmate, sometimes indistinct, primary venation; secondary venation reticulate. Inflorescences ageotropic or geotropic, pseudo-monochasial, perennial (shortlived in some extra-Australian species), interpetiolar (modified terminal), producing successive flushes of spirally inserted flowers in umbels. Pedicels unequal and forming a flat inflorescence, or equal and forming a globular inflorescence. Sepals free. Corolla connate, broad, campanulate or recurved, glabrous or puberulous, deeply lobed. Corona staminal, of variable shape and orientation, usually large and prominent; each scale with parallel, inrolled keels meeting beneath to create a cavity. Pollinia erect, oblong, winged on one side. Caudicles short, naked or winged. Corpuscle dark brown or black, triangular. Ovary superior, of two free carpels which are united at the stigma. Placentation axile, multiseriate on a single adaxial placenta. Fruit a linear follicle (rarely paired, one ovary usually aborting), adaxially dehiscent. Seeds oblong, with a multistranded silky coma.

\section{Key to the species}

1 Flowers more than $3.5 \mathrm{~cm}$ diam., red or purple

1. H. macgillivrayi

$1^{*}$ Flowers less than $3.0 \mathrm{~cm}$ diam., white, pink or yellow

2 Venation acrodromous, leaves distinctly 3-veined above

2. H. nicholsoniae

2* Venation not distinctly acrodromous

3 Pedicels unequal; venation obscurely subparallel without a distinct midrib

3. H. alata

$3^{*}$ Pedicels equal; venation pinnate or with a distinct midrib if obscure

4 Leaves abaxially densely tomentose, with patent hairs

4. H. australis

4* Leaves abaxially not densely patently tomentose 
5 Leaves finely appressed silky-hairy; sepals projecting beyond corolla sinuses 5. H. rupicola

$5^{*}$ Leaves glabrous or with widely scattered erect hairs; sepals not projecting beyond corolla sinuses 6. H. oligotricha

\section{Section Physostelma}

1. Hoya macgillivrayi Bailey, Queensland Agric. J. n.s. 1: 190, fig. 14 (1914).

TYPe CItAtion: 'Hab.: Claudie River, Lloyd Bay, Dr. W. Macgillivray'. Holotype: BRI.

A glabrous, twining epiphyte, rarely lithophytic or terrestrial. Leaves fleshy to coriaceous, broad-ovate to ovate, long-acute, cordate, broadly pinnately veined, shallowly concave above, $7-18 \mathrm{~cm}$ long, $3.5-8.0 \mathrm{~cm}$ wide; petioles $1.0-3.0 \mathrm{~cm}$ long, $3-7 \mathrm{~mm}$ diam. Peduncles $4-11 \mathrm{~cm}$ long, slender. Pedicels $6-10 \mathrm{~cm}$ long, slender. Umbels $4-15$ flowered. Sepals broadly triangular, 2-4 mm long. Corolla campanulate, purple or reddish brown, often with white patches towards the centre, $3.5-8.5 \mathrm{~cm}$ diam. Corona to $1.2 \mathrm{~cm}$ diam., purple; segments oblong-linear, 4.5-6 mm long, 1-2 $\mathrm{mm}$ wide, convex above, with two longitudinal, inrolled keels extending the full length below, inner angle sharply raised, outer angle raised. Fruit $15-19 \mathrm{~cm}$ long, $1.2-1.5 \mathrm{~cm}$ diam.

Endemic in Queensland, occurring in the Mcllraith and Iron Ranges of central Cape York Peninsula in dense monsoon rainforests.

Selected SPECIMENS: QueEnsland: Leo Creek road, B.P.M. Hyland 6378, 20.4.1972 (BRI, LAE, NSW); Massey Ck, K. Hill \& B. Wallace NSW 192779, 8.1978 (NSW) †; Leo Ck, K. Hill \& B. Wallace NSW 192778, 8.1978 (NSW)†; Lankelly Ck, D. Liddle IML 15, 9.1979 (NSW) †.

\section{Section Hoya}

2. Hoya nicholsoniae F. Muell., Fragm. 5: 159 (1866).

TYPE CITATION: 'In arboribus ad sinum litoreum Rockingham's Bay. Dallachy.' HOLOTYPE: MEL.

A glabrous, twining epiphyte, rarely lithophytic. Leaves fleshy to coriaceous, narrow-ovate to ovate, basally tapered, rounded or subcordate, usually green, red-brown when growing in strong light, 4-12 cm long, $2.5-7.0 \mathrm{~cm}$ wide; petioles $1.0-3.0 \mathrm{~cm}$ long, $4-8 \mathrm{~mm}$ diam., often with a pale brown corky surface. Peduncles $1-12 \mathrm{~cm}$ long, slender. Pedicels $6-10 \mathrm{~cm}$ long, slender. Umbels 10-30-flowered. Sepals triangular, $2-3 \mathrm{~mm}$ long. Corolla reflexed, pale yellow, $10-18 \mathrm{~mm}$ diam. Corona to $6 \mathrm{~mm}$ diam., flat, white; segments rhomboid, slightly longitudinally ridged above, with two longitudinal, inrolled keels extending the full length below, inner angle sometimes slightly lower, occasionally pale pink. Fruit $8-15 \mathrm{~cm}$ long, $0.7-1.2 \mathrm{~cm}$ diam.

A widespread and relatively abundant epiphyte or lithophyte in rainforests of northeastern Queensland, at low and high altitudes; also known in New Guinea but apparently not common. It also occurs epiphytically in mangrove communities. 
Leaf shape and colour are highly variable, and largely dependent on environmental factors.

One plant in cultivation at the Royal Botanic Gardens, Sydney, has distinctly spotted leaves and a slightly duller upper epidermis. This plant $(D$. Liddle IML 36, from the Atherton Tableland) is reported to have somewhat broader and more rounded corona segments, and may represent another taxon in this group.

Selected Specimens: Queensland: China Camp, S. of Cooktown, D.F. Blaxell 1081, 18.6.1973 (NSW); Black Mountain, SW of Cooktown, A.N. Rodd 211, 23.7.1965 (NSW); Pascoe River rockpile, B. Wallace 83253, 16.9.1983 (NSW) $\dagger$; Cooper Ck, P. Hind 190, 1.1972 (NSW) †; Cape Tribulation, W.W. Mason NSW 192780, 1.2.1947 (NSW) †; Barong logging area, P. Weston 979, 23.8.1986 (NSW)†; Daintree Ferry, K. Hill 2009, 8.8. 1986 (NSW); Mt Lewis, P. Hind 3621A, 27.4.1984 (NSW)†; D. Liddle IML 21 (NSW)†.

\section{Section Oreostemma}

\section{Hoya alata $K$. Hill, sp. nov.}

Ab Hoya poolei lobis coronae angustioribus, foliis latioribus et plus nitidis sed non basaliter auriculatis differt.

TyPE: QueEnSLAND: Pascoe River rockpile, B. Wallace 83250, 16.9.1983 (holo: NSW iso: $\mathrm{BRI}, \mathrm{K}, \mathrm{L}$ ).

Latin alata, 'winged', referring to the winged caudicles occurring only in this species among the Australian members of this genus.

A glabrous lithophytic or terrestrial twiner. Leaves fleshy to coriaceous, ovate or rhomboid, acute, tapering to a narrowly cordate base, pale green, pink or pale bronze when growing in strong light, 3-7 cm long, $2.5-5.0 \mathrm{~cm}$ wide; margins and apex recurved; venation obscure, sub-parallel or somewhat palmate, petioles 3-8 $\mathrm{mm}$ long, 2-4 mm diam. Peduncles 4-7 cm long, slender, geotropic. Pedicels $1-3 \mathrm{~cm}$ long, slender, unequal. Umbels 4-10-flowered. Sepals triangular, 1-2 mm long. Corolla recurved, distinctly pilose, pale pink or almost white, 8-14 mm diam. Corona 4-7 cm diam., creamy-white; segments oblong-linear, convex above, with two longitudinal, inrolled keels extending the full length below, inner angle raised, outer angle laid back. Fruit 7-14 cm long, $0.7-1.2 \mathrm{~cm}$ diam.

Distinguished from the New Guinea species $H$. poolei $\mathrm{C}$. White \& Francis by the narrower corona lobes and the broader, glossier leaves without distinctly sagittate bases.

Endemic to Cape York Peninsula, Queensland, presently known only from the Iron Range area northward. Locally common on rocky slopes and headlands. Although abundant in this region, this species remained undiscovered until the early 1970s. It is usually lithophytic on jumbled granite rock piles which outcrop throughout the higher rainfall parts of the Iron Range region.

Selected Specimens: QueEnsland: Iron Range, B. Gray NSW 192781, 1972 (NSW)†; Tozers Gap, K. Hill 1870, 29.7.1986 (NSW). 


\section{Section Pterostelma}

The Hoya australis complex. This group of taxa is centred on Australia and the South Pacific, with one outlying species extending through Malaysia to Indochina. The species are difficult to separate, as the flowers are uniform and virtually identical throughout the group. However, vegetatively distinguishable forms occur sympatrically in various parts of the range of the group. These forms are reproductively isolated, and are hence regarded as distinct species. Where clearly vegetatively distinguishable entities are not sympatric, definition of relationships is difficult, and certain entities are here somewhat arbitrarily recognized as species. Morphologically different (although similar) groups which apparently intergrade where ranges meet are recognized as subspecies.

\section{Hoya australis $R$. Br. ex Traill, Trans. Hort. Soc. 7: 28 (1830).}

TyPE Citation: ' . . native of the more northern part of New South Wales, with leaves varying from elliptic to obovate; this is in the herbarium of Mr. Robert Brown, and is named by him Hoya australis'.

TYPE: Typification is discussed by Britten (1898). The single collection in Brown's herbarium is apparently a Banks and Solander collection from 'Cape Grafton, Endeavour River' (two separate localities). This specimen (now in BM, n.v.) bears Brown's annotations ' $H$. carnosa' and ' $H$. australis', and can be regarded as the holotype. An isotype is in NSW.

A polymorphic taxon apparently distributed through Australia to New Guinea and some Pacific Islands. Several subspecies can be distinguished, all apparently intergrading to some extent. Two subspecies are recognized in Australia, with one more in New Guinea and an additional one in the Pacific Islands. The Australian representatives only are treated here.

\section{Key to the subspecies}

1 Leaves apically rounded, apiculate subsp. australis

1 * Leaves acute subsp. sana

\section{4a. Hoya australis subsp. australis}

Don, Gen. Syst. 4: 126 (1838); Decne. in DC., Prodr. 8: 640 (1844); Bentham, Fl. Austral. 4: 346 (1869); Britten, J. Bot. 36: 414 (1898); Bailey, Fl. Queensland 3: 1013 (1900); Domin, Bibl. Bot. 89: 1086 (1928); Smith, Sargentia 1: 110 (1942).

H. dalrympleana F. Muell., Rep. Burdekin Exped.: 16 (1861).

Type Citation: 'On Granite Hills at Cape Cleveland'. Holotype: MEL.

H. keysii Bailey, Proc. Roy. Soc. Queensland 1: 87 (1884).

Type Citation: 'Hab. Mount Perry, climbing over rocks (Jas. Keys)'. Holotype: BRI.

Illustrations: Britten, Illustr. Austral. Pl. Banks \& Solander 2: 620, t. 203 (1900); Bailey, Compr. Cat. Queensland Pl.: 334, fig. 309 (1913), as H. keysii.

A pubescent lithophytic or terrestrial twiner or shrub. Leaves fleshy, broadly pinnately veined, elliptical, ovate or orbicular, $3-6 \mathrm{~cm}$ long, $2.0-5.0 \mathrm{~cm}$ wide, densely pubescent beneath, loosely pubescent or \pm glabrous above; petioles $1.0-3.5 \mathrm{~cm}$ long, $3-7 \mathrm{~mm}$ diam. Peduncles $0.5-2.5 \mathrm{~cm}$ long, rhachis cylindrical. Pedicels $1.5-2.5 \mathrm{~cm}$ long, slender. Umbels $12-30$-flowered (rarely to 
40). Sepals broadly triangular, 2-3 mm long, Corolla campanulate, minutely puberulous within, creamy-white with a pink or red spot at the base of each lobe, $1.5-2.5 \mathrm{~cm}$ diam. Corona to $4 \mathrm{~mm}$ diam., white; segments ovate, concave above, with two longitudinal, inrolled keels extending the full length below, inner angle apiculate, outer angle rounded. Fruit $10-15 \mathrm{~cm}$ long, $1.0-1.5 \mathrm{~cm}$ diam. Fig. 1.

Distributed from the Cooktown district in Queensland south to the headwaters of the Richmond and Clarence Rivers in northern New South Wales. It extends from coastal headlands to subcoastal ranges in the north, but from Fraser Island southwards it appears to be restricted to the ranges, and is replaced by $H$. oligotricha subsp. oligotricha in the more coastal sites. It is usually lithophytic, scrambling often considerable distances over exposed rock outcrops and cliff faces.

Selected Specimens New South Wales: North Coast: Mt Sugarloaf, SW. of Casino, $S$. Clarke, J. Pickard \& R. Coveny 1828, 28.7.1969 (NSW); Rivertree, upper Clarence River, R.H. Cambage 2883, 7.9.1911 (NSW); Glenugie Peak, near Grafton, C.L. Wilson $586,7.4 .1957$ (NSW).

QueEnsLAnd: Davies Ck, H.S. McKee 9335, 25.4.1962 (NSW); Hinchinbrook Island, $P$. Hind 244, 8.1972 (NSW) †; Paluma Range, P. Hind 2669, 31.8.1980 (NSW) †; Byfield, $P$. Hind 3599, 21.4.1984 (NSW) †; Blackdown Tableland, P. Hind 3476, 7.4.1983 (NSW) †; Canungra, J.L. Boorman NSW 192782, 4.1907 (NSW).

\section{4b. Hoya australis subsp. sana (Bailey) $K$. Hill, comb. nov.}

BASIONYM: Hoya sana Bailey, Queensland Agric. J. 1: 229 (1897).

Type Citation: 'Hab.: Polo Creek, Somerset'. TyPe (holo?): BRI. A specimen in BRI which matches Bailey's description has been annotated 'possibly qualifies as lectotype if not holotype of $H$. sana/R. Henderson'. This specimen is from the type locality, but it bears no collector or date information.

Illustrations: Bailey, Compr. Cat. Queensland Pl.: 334, fig. 311 (1913).

A pubescent lithophytic or terrestrial twiner or shrub. Leaves fleshy, broadly pinnately veined, elliptical or ovate, $2-10 \mathrm{~cm}$ long, $1.5-6 \mathrm{~cm}$ wide, densely pubescent beneath, less so but still pubescent above; petioles $0.8-3.0 \mathrm{~cm}$ long, 3-7 mm diam. Peduncles $0.5-2.5 \mathrm{~cm}$ long, slender, rhachis cylindrical or subglobular. Pedicels $1.0-3.0 \mathrm{~cm}$ long, slender. Umbels 8-35-flowered. Sepals broadly triangular, 1-3 mm long. Corolla campanulate, minutely puberulous within, creamy-white with a pink or red spot at the base of each lobe, $0.8-2.0 \mathrm{~cm}$ diam. Corona to $4 \mathrm{~mm}$ diam., white; segments ovate; concave above, with two longitudinal, inrolled keels extending the full length below, inner angle apiculate, outer angle rounded. Fruit $7-15 \mathrm{~cm}$ long, $0.7-1.5 \mathrm{~cm}$ diam.

Ranges from the tip of Cape York and the Torres Strait Islands south to the Cooktown area. Zones of intergradation with subsp. australis occur around Cooktown and somewhat south of there. Subspecies sana is abundant in dense shrub heath on coastal dunes along the east coast of Cape York Peninsula, for example at McIvor River (to Cape Flattery) and Bolt Head. Plants are rooted in siliceous sand in these situations, climbing vigorously through the shrub canopy. This taxon also occurs lithophytically on exposed outcrops, rooting in small humus pockets and often forming small shrubby plants with short internodes and small leaves (e.g. upper Hann Creek). 
Selected SPecimens: QueEnSland: Escape River, J.R. Clarkson 2083, 4.6.1978 (BRI, NSW); Huxley Hill, Carron Valley, B. Wallace 83215, 14.9.1983 (NSW) $\dagger$; McIvor River heath, K. Hill 1091, 14.8.1984 (NSW) †; Captain Billy Creek, D. Liddle IML 31 (NSW)†; Upper Hann Creek, K. Hill 1782, 25.7.1986 (NSW, BRI); Dulhunty River crossing, $N$. Ollerenshaw 530, 10.7.1980 (NSW) †; Pascoe River rockpile, B.J. Wallace 831573, 8.1983 $(\mathrm{NSW}) \dagger ;$ D. Liddle IML 171 (NSW) $\dagger$; Silver Plains, P. Hind $3139(\mathrm{NSW})^{\dagger}$; Silver Valley, D. Liddle IML 6 (NSW) †*; Somerset, P. Lavarack NSW 193412 (NSW) $\dagger^{* *}$.

Specimens marked '*' are distinctly hairier on the upper leaf surface. This represents both seasonal variation, and also the range of variation within this taxon.

\section{Hoya rupicola $K$. Hill, sp. nov.}

Hoya australi affinis sed caulibus atque foliis minute sericeis et foliis carnosissimis, rhachidibus crassis sphaericisque, lobis calycis maioribus distinguenda.

Type: Northern Territory: Deaf Adder Gorge, R.E. Fox 2548, 24 Feb 1977 (holo: NSW; iso: CANB, DNA, NT).

Latin rupes, rupis, 'rock' or 'cliff', with the Latin compound ending -cola, 'dweller', referring to the habitat of this species on sandstone cliffs.

A highly succulent, minutely silky-tomentose lithophytic shrub or twiner. Leaves extremely fleshy, obscurely broadly pinnately veined, narrow-ovate to ovate, acute, basally tapered, pale grey-green, $5-14 \mathrm{~cm}$ long, $3.0-7.0 \mathrm{~cm}$ wide; petioles $1.0-2.0 \mathrm{~cm}$ long, $6-10 \mathrm{~mm}$ diam. Peduncles $1.0-2.5 \mathrm{~cm}$ long, slender. Pedicels $1.5-2.5 \mathrm{~cm}$ long. Umbels 10-30-flowered. Sepals oblong, 4-5 mm long. Corolla campanulate, densely minutely puberulous within, creamy-white with a pink or red spot at the base of each lobe, $1.0-2.5 \mathrm{~cm}$ diam. Corona to $4 \mathrm{~mm}$ diam., white, flat; segments ovate, concave above, with two longitudinal, inrolled keels extending the full length below, inner angle apiculate, outer angle rounded. Fruit 9-15 cm long, $1.0-1.5 \mathrm{~cm}$ diam.

Distinguished within the $H$. australis group by the highly succulent leaves with a persistent coating of fine silky hairs, the thick, subglobular rhachis and the large calyx.

Occurs on headlands and sandstone escarpments in the north of the Northern Territory and the Kimberley region of Western Australia. It is extremely succulent and drought resistant, growing in small humus accumulations usually on sandstone rocks, often in full sun. This region often receives no rainfall through the dry stage of the monsoon cycle, often for up to six months.

Selected SPECimens: Western Australia: summit of Mt Trafalgar, Prince Regent Reserve, A.S. George 12800, 29.8.1974 (PERTH); near source of Calder River, Kimberley distr., C.A. Gardner 1394, 20.6.1921 (PERTH, NSW); E2, Prince Regent Reserve, K.F. Kenneally s.n., 18.8.1974 (PERTH); Prince Regent Gorge, Bradshaw \& Allen, 4.4.1891 (MEL 73622).

NORTHERn TERritory: 2 miles [ $3 \mathrm{~km}$ ] W. of old BHP airstrip, $12^{\circ} 54^{\prime} \mathrm{S} 135^{\circ} 28^{\prime} \mathrm{E}$, D.E. Symon 7737, 12.12.1972 (ADW, PERTH); Umbrawarra Gorge, K. Hill 898, 14.7.1984 (NSW); Port Darwin, M. Holtze, 1890 (MEL 73611). 


\section{Hoya oligotricha $K$. Hill, sp. nov.}

Inter species australienses Hoya australis affinis foliis utrinque plus minusve glabris facile distinguenda.

Type: QueEnSLAND: Davies Creek, E. of Mareeba, D. Liddle NSW 193413 (holo: NSW†; iso: BRI, $\mathrm{K}, \mathrm{L}$ ).

Greek oligos, 'few', thrix, trichos, 'hairs', referring to the almost glabrous stems and leaves of this plant.

There are two subspecies, both endemic in Australia.

\section{Key to the subspecies}

1 New shoots distinctly loosely pubescent subsp. oligotricha

1* New shoots glabrous subsp. tenuipes

\section{6a. Hoya oligotricha subsp. oligotricha}

A vigorous, glabrous or very sparsely and loosely pubescent lithophytic or terrestrial twiner or shrub. Leaves fleshy, broadly pinnately veined, elliptical, ovate or orbicular, $4-12 \mathrm{~cm}$ long, $3.0-8.0 \mathrm{~cm}$ wide; petioles $1.0-3.5 \mathrm{~cm}$ long, $3-7 \mathrm{~mm}$ diam. Peduncles $0.5-2.5 \mathrm{~cm}$ long, rhachis cylindrical. Pedicels $1.5-3.0 \mathrm{~cm}$ long; slender. Umbels $12-30$-flowered. Sepals broadly triangular, 2-4 mm long. Corolla campanulate, minutely puberulous within, creamy-white with a pink or red spot at the base of each lobe, $1.5-2.5 \mathrm{~cm}$ diam. Corona to $4 \mathrm{~mm}$ diam., white; segments ovate, concave above, with two longitudinal, inrolled keels extending the full length below, inner angle apiculate, outer angle rounded. Fruit $10-15 \mathrm{~cm}$ long, $1.0-1.5 \mathrm{~cm}$ diam.

Distinguished by the broad leaves, the loosely pubescent new growth and the short, thick peduncles.

Many previous authors have mistakenly interpreted this taxon as representing $H$. australis (e.g. Bailey 1900).

Occurs on rocky outcrops in moist forests on and around the Atherton Tableland, extending south to Townsville. A disjunct occurrence further south extends from Fraser Island south to the Kempsey district. The southern occurence is almost exclusively coastal, on headlands and on siliceous sand in littoral rainforests or wet sclerophyll forests. Plants growing on dune systems are rooted directly into sand and usually have a long-twining, scrambling habit. Plants growing on rock outcrops are rooted in small humus accumulations, and show stronger development of the short-internode growth phase.

Selected Specimens: New South Wales: North Coast: Boonoo Boonoo, J.L. Boorman NSW 192783, 11.1904 (NSW); Brunswick Heads Nature Reserve, R. Coveny 9404, 4.5.1977 (NSW); Morgans Gully, Evans Head, R. Coveny 9374, 1.5.1977 (NSW); Iluka Nature Reserve, R. Coveny 9423, 6.5.1977 (NSW)†.

QueEnSLAND: Roaring Meg Falls, K. Hill 1974, 5.8.1986 (NSW)†; Walsh River, Atherton, R. Scott NSW 193091, 8.1978 (NSW)†; Rossville, P. Hind 3163, 12.6.1982 (NSW) $\dagger$; Mt Fraser, P. Hind 3209, 16.6.1982 (NSW)†; Noosa National Park, L.A.S. Johnson NSW 192784, 27.5.1951 (NSW). 
6b. Hoya oligotricha subsp. tenuipes $K$. Hill, ssp. nov.

A subspecie otigotricha foliis obovatis vel oblanceolatis utrinque glabris, pedunculis longioribus et tenuioribus differt.

Type: QueEnsland: Pascoe River Rockpile, B. Wallace 83252, 16.9.1978 (holo: NSW + ; iso: BRI, $K, L$ ).

Latin tenuis, 'slender', and pes, pedis, 'foot', referring to the more slender peduncles of this subspecies in comparison to the type subspecies.

A vigorous lithophytic or terrestrial twiner. Leaves fleshy or coriaceous, broadly pinnately veined, elliptical, narrow-ovate or narrow-obovate, 6-14 cm long, $3.0-7.0 \mathrm{~cm}$ wide; petioles $1.0-2.0 \mathrm{~cm}$ long, $3-7 \mathrm{~mm}$ diam. Peduncles $3.0-4.5 \mathrm{~cm}$ long, slender, rhachis cylindrical. Pedicels $2.0-4.0 \mathrm{~cm}$ long, slender. Umbels 10-25-flowered. Sepals narrowly triangular, 2-4 mm long. Corolla campanulate, minutely puberulous within, creamy-white with a pink or red spot at the base of each lobe, $1.0-2.0 \mathrm{~cm}$ diam. Corona to $4 \mathrm{~mm}$ diam., white; segments ovate, concave above, with two longitudinal, inrolled keels extending the full length below, inner angle apiculate, outer angle rounded. Fruit unknown.

$H$. oligotricha ssp. tenuipes is distinguished within the $H$. australis complex by the glabrous narrow-ovate or narrow-obovate leaves and the long, slender peduncles.

A taxon of rainforests of Cape York, from around the Olive River south through the Iron and McIlwraith Ranges. No collections of $H$. oligotricha are known from between the southern end of the McIlwraith Range and Cooktown, where $H$. oligotricha ssp. oligtricha is present. Subspecies tenuipes often occurs in deep shade in rainforests, growing as an epiphyte or lithophyte. It is sympatric with $H$. australis ssp. sana over much of its range. Scrub-clad rocky hills occur along the coast in areas such as the lower Pascoe River, with $H$. oligotricha ssp. tenuipes growing epiphytically within closed forest pockets in sheltered areas, and $H$. australis ssp. sana growing lithophytically on exposed rocks often only a few metres away. $H$. nicholsoniae often occurs with $H$. oligotricha ssp. tenuipes, and $H$. alata with $H$. australis ssp. sana in these situations.

Selected Specimens: QeEnSland: Hann Creek, B. Wallace 83236, 14.9.1983 (NSW)†; Mulingar, Mcllwraith Range, D. Liddle IML 25 (NSW) $\dagger$; Lankelly Creek, D. Liddle IML 27 (NSW)†; Tozers Gap, K. Hill 1871, 29.7.1986 (NSW, BRI).

\section{Excluded names}

Hoya carnosa $R . B r$.

Bentham (1869: 346) records $H$. carnosa for Queensland. This record is based on collections by Jardine of Somerset Station at the tip of Cape York which were sent to Mueller and then on loan to Bentham. One specimen (MEL 73617) bears the annotation ' $H$. carnosa / Cape York / Jardine' in Mueller's handwriting, with no further information. The other (MEL 73618) is labelled 'Hoya jardiniana / F.v.M. inedit. / Cape York / Jardine'. They match perfectly $H$. carnosa, recorded only from Hong Kong and China. This species has long been a popular ornamental plant, and Jardine was known to have cultivated a number of exotic plants at Somerset (e.g. the palm Borassus flabellifer, still growing on the site in 1985, fide P. Hind, Royal Botanic Gardens, Sydney). It is 
most likely that the specimens of $H$. carnosa sent to Mueller were taken from a cultivated plant at Somerset, as there are no other records of this taxon from Australia or nearby South-East Asian countries.

Hoya bicarinata A. Gray, Proc. Amer. Acad. Arts 5: 535 (1862).

Bentham (1869) records this name in synonymy with $H$. australis. The type of $H$. bicarinata was collected in Fiji, and represents a common South Pacific Island member of the $H$. australis complex which is not the same as any of the Australian species. H. bicarinata is characterised by large, orbicular leaves with a loose, open indumentum of long, erect hairs on each side.

\section{Acknowledgements}

The staff of the herbaria BRI, MEL, CANB, CBG, LAE and PERTH are gratefully acknowledged for assistance with access to collections and loan of specimens. The staff of the Living Collections division of the Royal Botanic Gardens, Sydney, have maintained a large living collection for research and study. David Liddle supplied living and preserved specimens of many North Queensland plants. Peter Wilson assisted with Latin diagnoses. David Mackay drew the figure.

\section{References}

Backer, C.A. \& R.C. Bakhuizen (1965) 'Flora of Java'. Vol. 2 (Noordhoff: Groningen). Bailey, F.M. (1900) 'Flora of Queensland'. Vol. 3 (Diddams: Brisbane).

Bentham, G. (1869) 'Flora Australiensis'. Vol. 4 (Reeve: London).

Britten, J. (1898) Notes on Hoya. J. Bot. 36: 414.

Brown, R. (1810) On the Asclepiadeae. Mem. Wern. Nat. Hist. Soc. 1: 12-78.

Demeter, K. (1922) Vergleichende Asclepiadeen-studien. Flora 115: 130-176.

Rintz, R.E. (1978) The peninsular Malaysian species of Hoya (Asclepiadaceae). Malayan Nat. J. 30: 467-522.

Rumphius (1749) 'Herbarium Amboinense' (Uytwerf: Amsterdam).

Schlechter, R. (1913) Die Asclepiadaceen von Deutsche-Neu-Guinea. Bot. Jahrb. Syst. 50: $104-138$.

Schumann, K. (1895) Asclepiadaceae. In A. Engler \& K. Prantl (eds), 'Die Naturlichen Pflanzenfamilien'. Teil 4, Abteil. 2 (Engelmann: Leipzig).

Traill, J. (1830) Description of plants belonging to the genus Hoya. Trans. Hort. Soc. London 7: 28.

Manuscript received 7 April 1987

Manuscript accepted 21 August 1987 